\title{
Exocervix Tumor
}

National Cancer Institute

\section{Source}

National Cancer Institute. Exocervix Tumor. NCI Thesaurus. Code C159623.

An indication that the tumor is in the exocervix. 